Article

\title{
Biological Activities and Chemical Constituents of Essential Oils from Piper cubeba Bojer and Piper nigrum L.
}

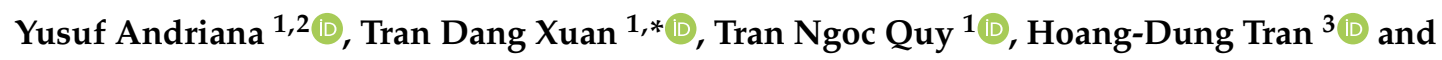 \\ Quang-Tri Le ${ }^{4}$ \\ 1 Graduate School for International Development and Cooperation, Hiroshima University, \\ Hiroshima 739-8529, Japan; yusufandriana@yahoo.com (Y.A.); tnquy@ctu.edu.vn (T.N.Q.) \\ 2 Research Center for Appropriate Technology, Indonesian Institute of Sciences, Jl. KS. Tubun No. 5, \\ Subang 41213, Indonesia \\ 3 Faculty of Biotechnology, Nguyen Tat Thanh University, 298A-300A Nguyen Tat Thanh Street, Ward 13, \\ District 4, Ho Chi Minh City 72820, Vietnam; thdung@ntt.edu.vn \\ 4 Department of Orthopedic, 7A Military Hospital, 466 Nguyen Trai Street, Ward 8, District 5, \\ Ho Chi Minh City 72706, Vietnam; bstridongnai@yahoo.com.vn \\ * Correspondence: tdxuan@hiroshima-u.ac.jp; Tel./Fax: +81-82-424-424-6927
}

Academic Editor: Derek McPhee

Received: 21 April 2019; Accepted: 15 May 2019; Published: 15 May 2019

check for updates

\begin{abstract}
In this study, we evaluated antioxidant, antihyperuricemic, and herbicidal activities of essential oils (EOs) from Piper cubeba Bojer and Piper nigrum L.; two pepper species widely distributed in tropics, and examined their chemical compositions. Dried berries of P. cubeba and P. nigrum were hydro-distilled to yield essential oil (EO) of 1.23 and $1.11 \%$ dry weight, respectively. In the antioxidant assay, the radical scavenging capacities of $P$. cubeba EO against DPPH and ABTS free radicals were 28.69 and $24.13 \%$ greater than P. nigrum, respectively. In the antihyperuricemic activity, P. cubeba EO also exhibited stronger inhibitory effects on xanthine oxidase $\left(\mathrm{IC}_{50}=54.87 \mu \mathrm{g} / \mathrm{mL}\right)$ than $P$. nigrum EO $\left(\mathrm{IC}_{50}=77.11 \mu \mathrm{g} / \mathrm{mL}\right)$. In the herbicidal activity, P. cubeba $\mathrm{EO}$ showed greater inhibition on germination and growth of Bidens pilosa and Echinochloa crus-galli than P. nigrum EO. Besides, P. cubeba EO decreased 15.98-73.00\% of photosynthesis pigments of B. pilosa and E. crus-galli, while electrolyte leakages, lipid peroxidations, prolines, phenolics, and flavonoids contents were increased $10.82-80.82 \%$ at $1.93 \mathrm{mg} / \mathrm{mL}$ dose. Gas chromatography-mass spectrometry (GC-MS) and liquid chromatography-electrospray ionization-mass spectrometry (LC-ESI-MS) analyses revealed that $P$. nigrum and P. cubeba EOs principally possessed complex mixtures of monoterpenes and sesquiterpenes. Terpinen-4-ol (42.41\%), $\alpha$-copaene $(20.04 \%)$, and $\gamma$-elemene $(17.68 \%)$ were the major components of $P$. cubeba EO, whereas $\beta$-caryophyllene $(51.12 \%)$ and $\beta$-thujene $(20.58 \%)$ were the dominant components of $P$. nigrum EO. Findings of this study suggest both $P$. cubeba and $P$. nigrum EOs were potential to treat antioxidative stress and antihyperuricemic related diseases. In addition, the EOs of the two plants may be useful to control B. pilosa and E. crus-galli, the two invasive and problematic weeds in agriculture practice.
\end{abstract}

Keywords: Piper cubeba; Piper nigrum; essential oil; antioxidant; antihyperuricemia; Bidens pilosa; Echinochloa crus-galli

\section{Introduction}

Essential oils (EOs) of plants have been extensively used in food, cosmetic, healthcare, and agriculture industries [1,2]. EO is the hydrophobic liquid containing volatile aromatic compounds and usually extracted from plants tissues by hydro-distillation [3]. It is considered of great 
importance due to its biological properties, for example antioxidant, anti-aging, anti-melanogenic, anti-inflammatory, anti-fungal, or anti-aflatoxin capacity [2,4]. In herbicidal activity, essential oils extracted from Tagetes erecta, Satureja hortensis, Citrus aurantiifolia, and Tetraclinis articulate have been reported to have phytotoxic property on some weed species [1,5-7].

The genus Piper (Piperaceae family) consists of more than 700 species distributed in tropical and subtropical regions in the world and is used mainly for spices and seasonings. Traditionally, this genus is employed to treat inflammation, skin irritation, bronchitis, and intestinal pains [8,9]. Some EOs from this genus for example P. gaudichaudianum, P. humaytanum, P. permucronatum, and P. hostmanianum exhibit larvicidal activity [10]. Another species, such as P. angustifolium EO possesses antileishmanial capacity [11]. In comparison to other species from the genus of Piper, biological activities of Piper cubeba and Piper nigrum EOs have received less attention so far and have not yet been well documented.

P. cubeba, or tailed pepper, a plant originated from Java and Borneo, sometimes called as Java pepper, is mostly cultivated for its berries and essential oil [12]. Normally, this plant is utilized as a traditional medicine to treat gonorrhea, dysentery, syphilis, abdominal pain, diarrhea, enteritis, and asthma diseases [13]. Some biological activities of P. cubeba EO for instance antiparasitic [14], antimicrobial [15], insecticidal activities [16] have been reported. Sabinene, $\beta$-elemene, and cubebol are the principal components of P. cubeba EO extracted from its berries [17].

P. nigrum, or black pepper, is native in Kerala in Southwestern India and widely distributed in tropical regions, including Indonesia. Its fruits are usually dried and used for spices and seasonings. This plant is used as a folk medicine to treat gastrointestinal disorder, rheumatic, flu, colds, muscular aches, and fever diseases [12]. Biological activities of P. nigrum EO have been known as insecticidal [18,19], larvicidal [20], antioxidant [12], and antimicrobial activities [21]. Caryophyllene and limonene have been reported as the dominant compounds of $P$. nigrum EO [22]. For antihyperuricemia, ethanol, water, and methanol extracts of P. nigrum, and piperine, have been known to be active substances against xanthine oxidase [23-25]. However, the inhibitory effect of essential oil of this plant on xanthine oxidase to the best of our knowledge is still unknown.

The present study evaluated antioxidant, antihyperuricemic, and herbicidal activities of P. cubeba and P. nigrum EOs, and examined their chemical compositions. Xanthine oxidase, the key enzyme played vital roles to cause hyperuricemia and gout, was employed to evaluate inhibitory capacity of these EOs. Two noxious weeds, B. pilosa and E. crus-galli, were selected as indicator plants in herbicidal assays. Physiological and biochemical responses of the two indicator plants to P. cubeba and P. nigrum EOs were also evaluated.

\section{Results}

\subsection{Antioxidant and Antihyperuricemic Activities}

Antioxidant and antihyperuricemic activities of P. cubeba and P. nigrum EOs were presented in Table 1. P. cubeba EO showed higher inhibitory effects on both antioxidant and antihyperuricemic activities. The $\mathrm{IC}_{50}$ values of $P$. cubeba $\mathrm{EO}$ in DPPH and ABTS assays were 0.28 and 0.24 -folds stronger than P. nigrum. In line with antioxidant capacity, P. cubeba EO also exhibited more inhibitory effect on xanthine oxidase than P. nigrum. However, compared with BHT and allopurinol as positive controls of antioxidant and XOI activities, both of EOs presented lower inhibitory effects. 
Table 1. Antioxidant and xanthine oxidase inhibitory activities of EOs from P. cubeba and P. nigrum.

\begin{tabular}{cccc}
\hline \multirow{2}{*}{ Samples } & \multicolumn{2}{c}{ Antioxidant Activity $\left(\mathrm{IC}_{\mathbf{5 0}}(\mathbf{m g} / \mathbf{m L})\right)$} & \multirow{2}{*}{ XOI Activity $\left(\mathbf{I C}_{\mathbf{5 0}}(\boldsymbol{\mu} \mathbf{g} / \mathbf{m L})\right)$} \\
\cline { 2 - 3 } & DPPH & ABTS & \\
\hline P. cubeba EO & $0.82 \pm 0.06^{b}$ & $1.32 \pm 0.04^{b}$ & $54.87 \pm 1.69^{a b}$ \\
P. nigrum EO & $1.15 \pm 0.08^{a}$ & $1.74 \pm 0.03^{a}$ & $77.11 \pm 2.11^{a}$ \\
BHT $^{*}$ & $0.009 \pm 0.02^{c}$ & $0.071 \pm 0.001^{c}$ & - \\
Allopurinol & - & - & $20.45 \pm 0.3^{b}$ \\
\hline
\end{tabular}

Data presented means \pm standard deviations (SD). Values in the same column followed by similar letters are not significantly different by Fisher' $(p<0.05) .{ }^{*}=$ positive control for antioxidant assay. ${ }^{* *}=$ positive control for xanthine oxidase inhibitory assay. - = not determined.

\subsection{Herbicidal Activity of P. cubeba and P. nigrum EOs against B. pilosa and E. crus-galli}

The inhibitory effects $\left(\mathrm{IC}_{50}\right)$ of P. cubeba and P. nigrum EOs on germination and growth of two noxious weeds, B. pilosa and E. crus-galli, were indicated in Table 2. The values of $\mathrm{IC}_{50}$ of the two EOs on germination and growth of indicator plants were varied. Inhibitory effects of P. cubeba EO on the roots and shoots elongation of B. pilosa were 4.16 and $37.74 \%$ stronger than P. nigrum respectively. Similarly, P. cubeba EO gave more $18.72 \%$ inhibition effects on the shoot growth of E. cruss-gali than P. nigrum EO. It appears that $P$. cubeba EO may contain more growth inhibitors than P. nigrum EO.

Table 2. Inhibition $\left(\mathrm{IC}_{50}\right)$ values of P. cubeba and P. nigrum EOs on some indicator plants.

\begin{tabular}{ccccc}
\hline \multirow{2}{*}{ Treatments } & \multirow{2}{*}{ Indicator Plants } & \multicolumn{3}{c}{ IC $_{\mathbf{5 0}}(\mathbf{m g} / \mathbf{m L})$} \\
\cline { 3 - 5 } & & Germination & Roots & Shoots \\
\hline \multirow{2}{*}{ P. cubeba EOs } & B. pilosa & $5.19 \pm 0.22^{a}$ & $2.63 \pm 0.58^{a}$ & $1.93 \pm 0.68^{b}$ \\
& E. crus-galli & $5.26 \pm 0.34^{a}$ & $3.30 \pm 0.97^{a}$ & $5.86 \pm 0.94^{a b}$ \\
\hline \multirow{2}{*}{ P. nigrum EOs } & B. pilosa & $5.44 \pm 0.00^{a}$ & $2.67 \pm 0.64^{a}$ & $3.1 \pm 0.56^{a b}$ \\
& E. crus-galli & $>8.00$ & $2.71 \pm 0.11^{a}$ & $7.21 \pm 2.02^{a}$ \\
\hline
\end{tabular}

Data were presented in means \pm standard deviations (SD). Different letter in a column indicated significantly different by Fisher's test $(p<0.05)$.

\subsection{Physiological and Biochemical Responses of B. pilosa and E. crus-galli to P. cubeba and P. nigrum EOs}

\subsubsection{Pigments Contents}

The responses of B. pilosa and E. crus-galli in chlorophylls and carotenoids contents to P. cubeba and P. nigrum EOs were presented in Figure 1. Both of EOs decreased chlorophyll a, b, total chlorophylls, and carotenoids contents of B. pilosa and E. crus-galli ranged from 15.98 to $73.00 \%$ compare with control. Compared with P. nigrum, P. cubeba EO decreased B. pilosa and E. crus-galli pigment more effective by 49.84 and $48.24 \%$ in chlorophyll a; 41.76 and $48.79 \%$ in chlorophyll b; 47.26 and $48.41 \%$ in total chlorophylls; 49.43 and $46.44 \%$ in carotenoids contents respectively.

\subsubsection{Electrolyte Leakage}

The variation of electrolyte leakage (EL) from the roots and aerial parts of treated and untreated B. pilosa and E. crus-galli by EOs were presented in Figure 2. Generally, EOs treatments increased EL percentage compared with control. Compared with P. nigrum, P. cubeba EO gave more effects in increasing of electrolyte leakage percentage in the roots and aerial parts of B. pilosa than E. crus-galli after $24 \mathrm{~h}$ and $48 \mathrm{~h}$ treatments. The leakages were greater after $48 \mathrm{~h}$, compared with $24 \mathrm{~h}$. 


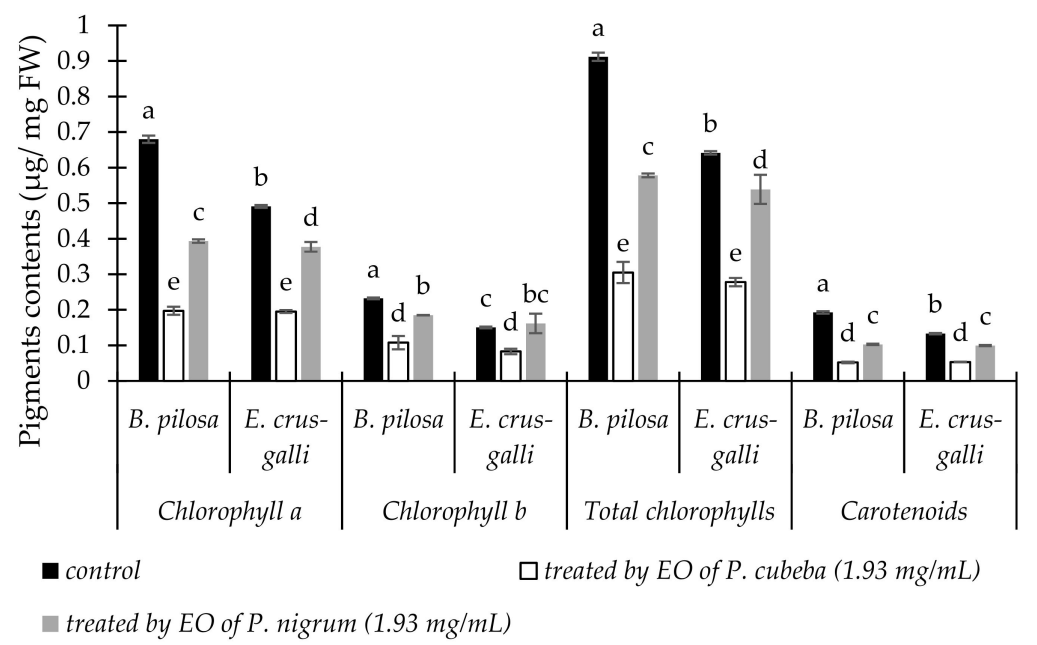

Figure 1. The changes of pigment contents of B. pilosa and E. crus-galli between control and treatments. Data were presented in means \pm standard deviations (SD). Means with different small letter in the same pigment indicted significantly different by Fisher's test $(p<0.05)$.

$24 \mathrm{~h}$

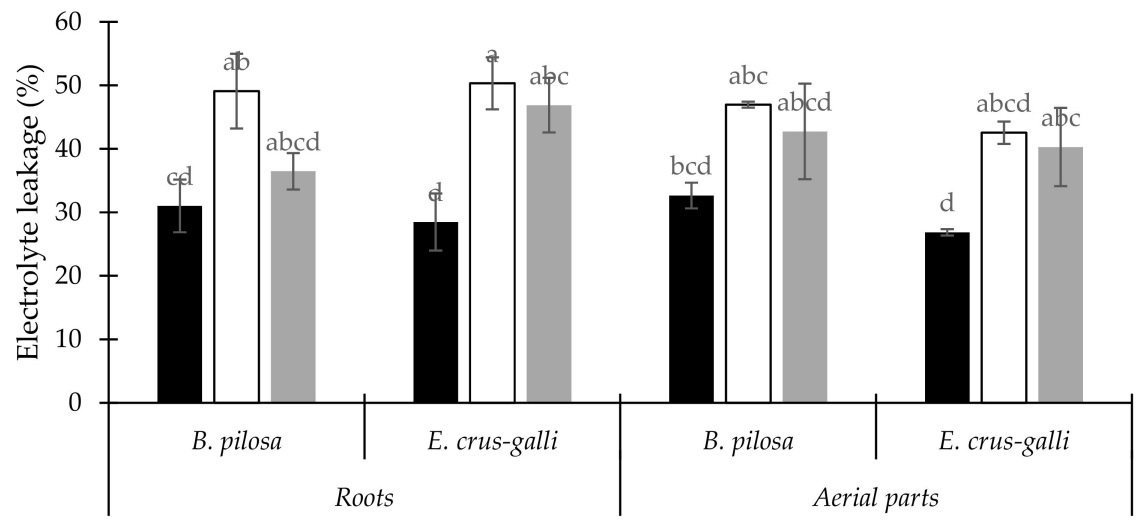

- control $\square$ treated by EO of P. cubeba $(1.93 \mathrm{mg} / \mathrm{mL}) \square$ treated by EO of P. nigrum $(1.93 \mathrm{mg} / \mathrm{mL})$

(a)

$48 \mathrm{~h}$

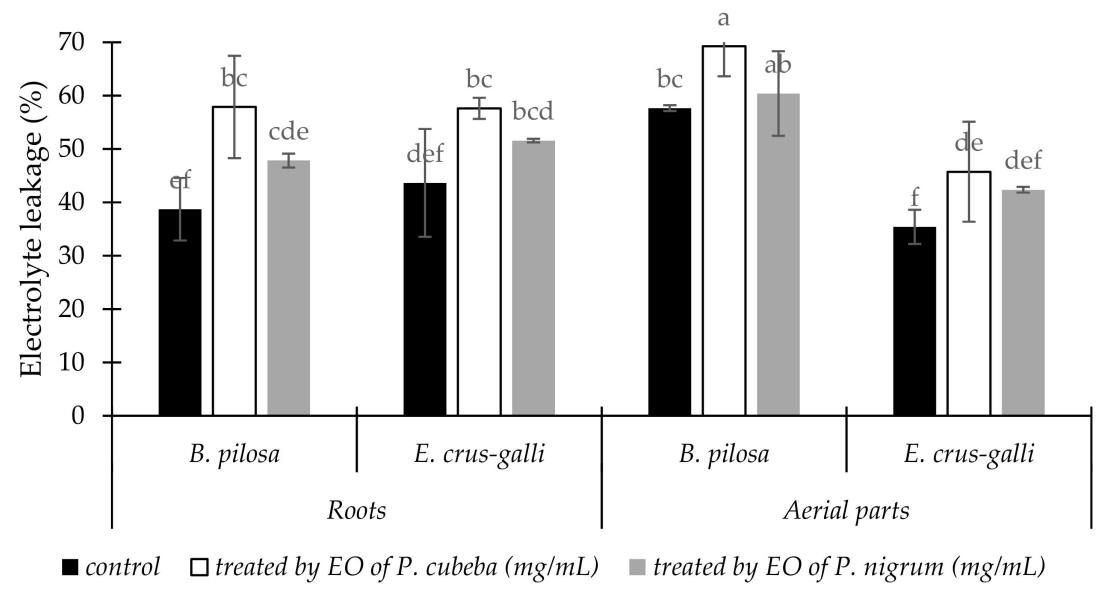

(b)

Figure 2. The changes of electrolyte leakage (\%) of B. pilosa and E. crus-galli between control and treatments after $24 \mathrm{~h} \mathrm{(a)} \mathrm{and} 48 \mathrm{~h}(\mathbf{b})$. Data were presented in means \pm standard deviations (SD). Means with different small letter indicted significantly different by Fisher's test $(p<0.05)$. 


\subsubsection{Lipid Peroxidation}

The responses of B. pilosa and E. crus-galli to P. cubeba and P. nigrum EOs treatments in lipid peroxidation accumulations were presented in Figure 3. Lipid peroxidation, expressed as malondialdehyde (MDA) contents, were increased significantly in both EOs treatments compared with control. Accumulation of MDA in E. crus-galli was the highest as responses of EOs treatments. Compared with P. nigrum EO, P. cubeba EO gave more stimulation effects in MDA accumulation both in B. pilosa and E. cruss-galli. P. cubeba EO induced MDA accumulation both in B. pilosa and E. crus-galli by 37.46 and $50.18 \%$ in the roots and 11.26 and $10.82 \%$ in the aerial parts respectively.

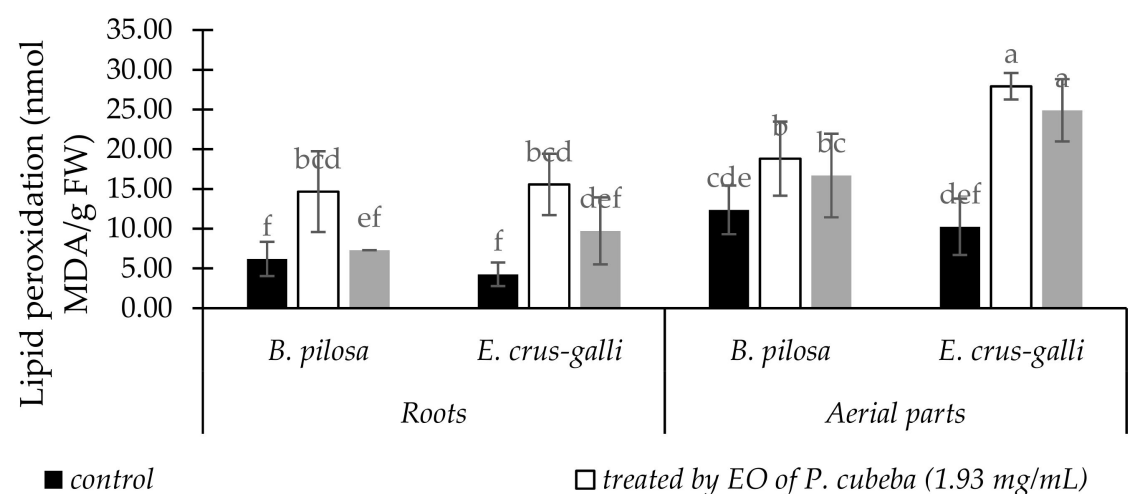

treated by $E O$ of $P$. nigrum $(1.93 \mathrm{mg} / \mathrm{mL})$

Figure 3. The changes of MDA content between treated and untreated of B. pilosa and E. crus-galli by EOs. Data were presented in means \pm standard deviations (SD). Means with different small letter indicted significantly different by Fisher's test $(p<0.05)$.

\subsubsection{Total Phenolic Contents}

Total phenolic contents of B. pilosa and E. crus-galli in the roots and aerial parts as response of EOs treatments were indicated in Figure 4. Compared with control, total phenolic contents (TPC) in the EOs treatments of two indicator plants were increased significantly. P. cubeba EO gave more stimulation effect on total phenolic accumulations of B. pilosa and E. crus-galli by 80.82 and $26.54 \%$ in the roots and 21.47 and $50.97 \%$ in the aerial parts, respectively than P. nigrum.

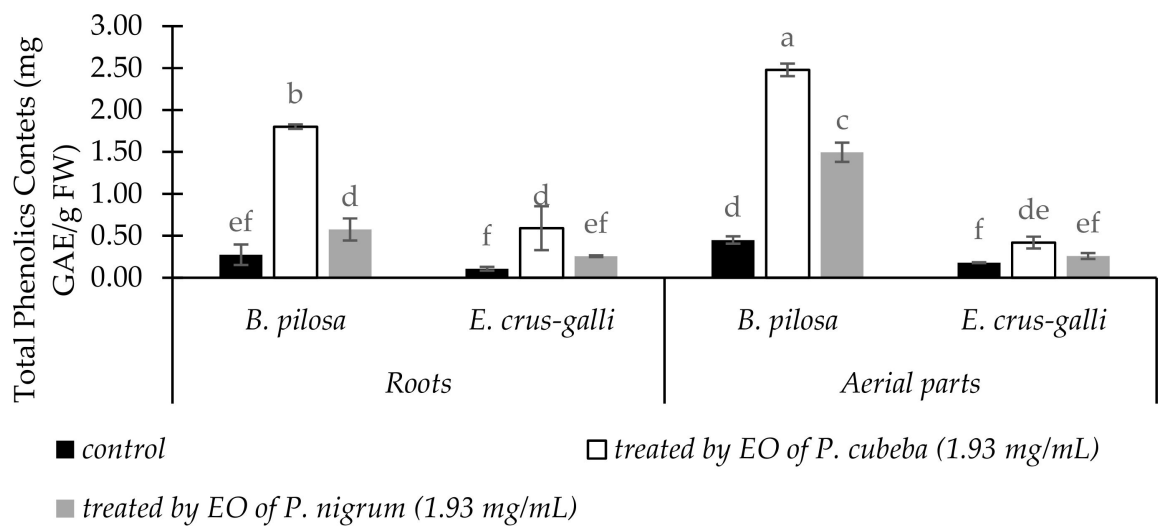

Figure 4. The changes of TPC in the roots and aerial parts of between treated and untreated of B. pilosa and E. crus-galli by P. cubeba and P. nigrum EOs. Data were presented in means \pm standard deviations (SD). Means with different small letter indicted significantly different by Fisher's test $(p<0.05)$.

\subsubsection{Total Flavonoid Contents}

Total flavonoid contents (TFC) in the roots and aerial parts between treated and untreated of B. pilosa and E. crus-galli were showed in Figure 5. Both in the roots and aerial parts of B. pilosa and 
E. crus-galli, TFC were increased significantly when treated by EOs compared with control. The aerial parts of $B$. pilosa showed the maximum response in total flavonoids accumulations. P. cubeba EO gave more stimulation of total phenol accumulation for B. pilosa and E. crus-galli by 68.04 and $56.46 \%$ in the roots and 39.67 and $39.19 \%$ in the aerial parts respectively than P. nigrum.

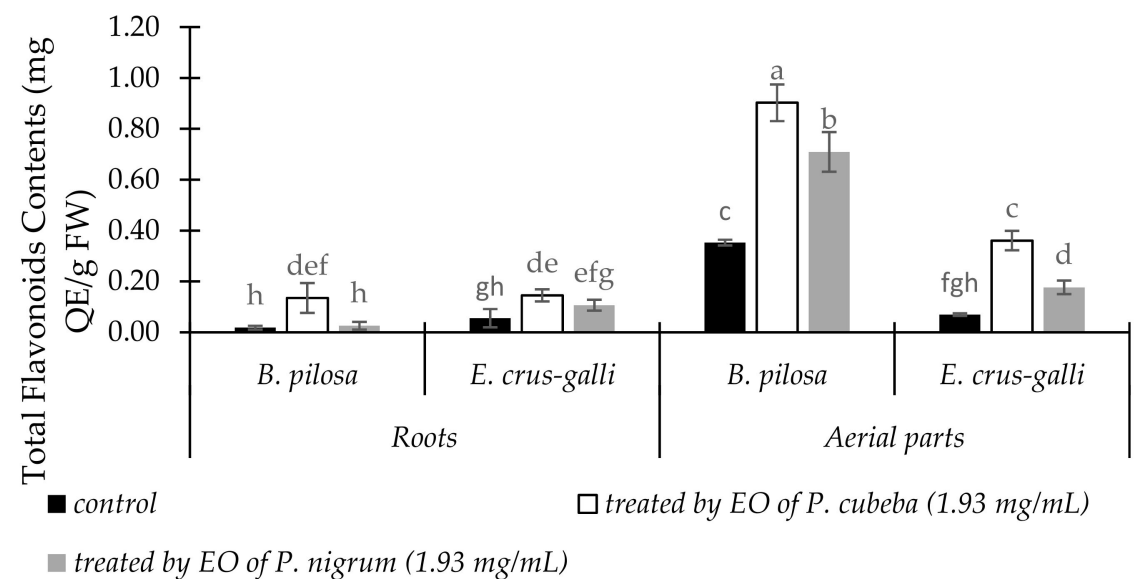

Figure 5. The changes of TFC in the roots and aerial parts of between treated and untreated of B. pilosa and E. crus-galli by P. cubeba and P. nigrum EOs. Data were presented in means \pm standard deviations (SD). Means with different small letter indicted significantly different by Fisher's test $(p<0.05)$.

\subsubsection{Proline Contents}

The responses of B. pilosa and E. crus-galli between untreated and treated by P. cubeba or P. nigrum EOs in the proline accumulations were indicated in Figure 6. In the roots, effects of P. cubeba and P. nigrum EOs in proline accumulation of the two indicator plants were negligible compared with control. In contrast, in the aerial parts proline accumulations between control and treated indicator plants were significantly different. Compare with P. nigrum, P. cubeba EO stimulated 16.23 and $18.08 \%$ higher in proline accumulations of B. pilosa and E. crus-galli respectively.

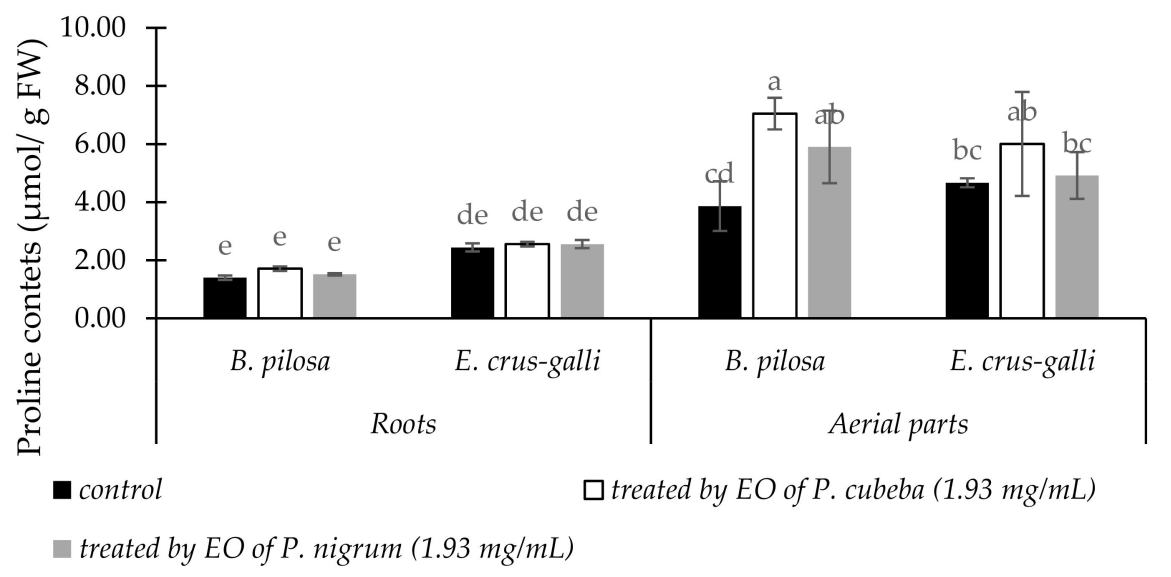

Figure 6. The changes of proline in the roots and aerial parts of between treated and untreated B. pilosa and E. crus-galli by P. cubeba and P. nigrum EOs. Data were presented in means \pm standard deviations (SD). Means with different small letter indicted significantly different by Fisher's test $(p<0.05)$.

\subsubsection{Essential Oil Yields}

EOs yields of P. cubeba and P. nigrum were presented in Table 3. The yields of P. cubeba and P. nigrum EOs were significantly different. P. cubeba yielded more EO $(1.23 \% w / w)$ compared with P. nigrum $(1.11 \% w / w)$. 
Table 3. Yields of essential oils extracted from P. cubeba and P. nigrum.

\begin{tabular}{cccc}
\hline Samples & Dry Weight $(\mathrm{g})$ & EOs $(\mathrm{g})$ & $\begin{array}{c}\text { Yields }(\% \boldsymbol{w} / \boldsymbol{w}) \\
(\% \boldsymbol{w} / \boldsymbol{w} \mathbf{D W})\end{array}$ \\
\hline P. cubeba & 300.00 & $3.69 \pm 0.05^{a}$ & $1.23 \pm 0.01^{a}$ \\
P. nigrum & 300.00 & $3.35 \pm 0.01^{b}$ & $1.11 \pm 0.01^{b}$
\end{tabular}

Data were presented in means \pm standard deviations (SD). Different letter in a column indicted significantly different by Fisher's test $(p<0.05)$.

\subsubsection{Chemicals Composition of P. cubeba and P. nigrum Essential Oils}

The chemical components of EOs from P. cubeba and P. nigrum by GC-MS and confirmed by LC-ESI-MS were indicated in Table 4 (Supplementary Materials Figures S1-S24 and Tables S1-S22). Both of EOs contained a complex mixture mainly consisting mainly of monoterpenes and sesquiterpenes.

Table 4. Identification of chemical components of P. cubeba and P. nigrum EOs by GC-MS.

\begin{tabular}{|c|c|c|c|c|c|c|c|c|}
\hline No. & Compounds & $\underset{(\mathrm{min})}{\mathrm{Rt}}$ & $\begin{array}{l}\text { Chemical } \\
\text { Formula }\end{array}$ & $\begin{array}{c}\text { MW } \\
(\mathrm{g} / \mathrm{mol})\end{array}$ & Chemical Class & \multicolumn{2}{|c|}{ Area $(\%)$} & $\mathbf{R I}$ * \\
\hline 1 & $\beta$-Thujene & 5.32 & $\mathrm{C}_{10} \mathrm{H}_{16}$ & 136.238 & Monoterpenes & - & 20.58 & 929 \\
\hline 3 & trans-Chrysanthenyl acetate & 8.38 & $\mathrm{C}_{12} \mathrm{H}_{18} \mathrm{O}_{2}$ & 194.274 & Monoterpenes & 0.1 & - & 1228 \\
\hline 4 & $\delta$-EIemene & 9.96 & $\mathrm{C}_{15} \mathrm{H}_{24}$ & 204.357 & Monoterpenes & 0.58 & 5.03 & 1338 \\
\hline 5 & $\alpha$-Cubebene & 10.13 & $\mathrm{C}_{15} \mathrm{H}_{24}$ & 204.357 & Sesquiterpenes & 6.54 & - & 1349 \\
\hline 8 & $\gamma$-Elemene & 11.21 & $\mathrm{C}_{15} \mathrm{H}_{24}$ & 204.357 & Sesquiterpenes & 17.68 & - & 1455 \\
\hline 9 & $\beta$-Caryophyllene & 11.23 & $\mathrm{C}_{15} \mathrm{H}_{24}$ & 204.357 & Sesquiterpenes & - & 51.12 & 1467 \\
\hline 10 & Humulene & 11.60 & $\mathrm{C}_{15} \mathrm{H}_{24}$ & 204.357 & Sesquiterpenes & - & 3.81 & 1474 \\
\hline 11 & $\beta$-Selinene & 12.03 & $\mathrm{C}_{15} \mathrm{H}_{24}$ & 204.357 & Sesquiterpenes & - & 5.59 & 1490 \\
\hline 12 & $\delta$-Cadinene & 12.33 & $\mathrm{C}_{15} \mathrm{H}_{24}$ & 204.357 & Sesquiterpenes & 2.7 & 2.04 & 1525 \\
\hline 13 & $\alpha$-Elemol & 12.68 & $\mathrm{C}_{15} \mathrm{H}_{26} \mathrm{O}$ & 222.372 & Sesquiterpenes & 1.78 & - & 1551 \\
\hline
\end{tabular}

$\mathrm{Rt}=$ retention time of GC-MS. MW= molecular weight. $-=$ not detected. $\mathrm{RI}=$ retention index, ${ }^{*}$ calculated according to Kovat's index based on NIST Mass Spectral Library [26].

The major compounds of P. cubeba EO were terpinen-4-ol (42.41\%), followed by $\alpha$-copaene $(20.04 \%), \gamma$-elemene $(17.68 \%), \alpha$-cubebene $(6.54 \%)$, and D-germacrene $(2.50 \%)$. Whereas P. nigrum EO contained the dominant components of $\beta$-caryophyllene (51.12\%), $\beta$-thujene $(20.58 \%), \beta$-selinene (5.59\%), $\delta$-elemene $(5.03 \%)$, and $\alpha$-copaene $(4.79 \%)$.

\section{Discussion}

The safety and environmentally friendly of natural substances used in drugs, health foods, or natural herbicides are the major concern of many researchers. Several studies have explored the biological activities of P. cubeba or P. nigrum EOs such as antioxidant [12,27], anti-larvicidal [10], and insecticidal activities [28]. This study is the first report in comparison of the antihyperuricemic and herbicidal activities of P. cubeba and P. nigrum EOs. Our study demonstrated that P. cubeba and $P$. nigrum EOs possessed antioxidant, antihyperuricemic, and herbicidal activities.

In the antioxidant assay, P. cubeba EO had more anti-radical scavenging activity against DPPH and ABTS than P. nigrum. However, compared with BHT as positive control, both of the EOs exhibited lower antioxidant capacities. The GC-MS and LC-ESI-MS analyses indicated that terpinen-4-ol $(42.41 \%)$, $\alpha$-copaene $(20.04 \%)$, and $\gamma$-elemene (17.68\%) were the major components of P. cubeba EO. In line with our results, terpinen-4-ol has been reported to have antioxidant activities [4,29]. Whilst for P. nigrum EO, $\beta$-caryophyllene (51.12\%) and $\beta$-thujene (20.58\%) accounted as the main components. $\beta$-caryophyllene is a compound belongs to sesquiterpenes group. This compound has also been reported to possess 
antioxidant activity [4]. Antioxidant activity of P. nigrum has been reported for its methanol, ethanol, and water extracts, and essential oil [12,26]. However, for P. cubeba, to the best of our knowledge only methanol, ethanol, and water extracts have been reported [12], while antioxidant activity of its essential is remain unknown. Antioxidant properties of P. nigrum and P. cubeba EOs in this study may be attribute to the presence of terpinen-4-ol and $\beta$-caryophyllene, respectively. Thus, our results suggest that P. cubeba and P. nigrum EOs may be useful for anti-oxidative stress treatment.

In the antihyperuricemic activitiy, $P$. cubeba and $P$. nigrum EOs possessed ability to inhibit xanthine oxidase. However, the inhibitory effects of the two EOs were lower than allopurinol $(20.45 \mu \mathrm{g} / \mathrm{mL})$ as positive control of xanthine inhibitory assay. Compared with P. nigrum, P. cubeba $\mathrm{EO}\left(\mathrm{IC}_{50}=54.87 \mu \mathrm{g} / \mathrm{mL}\right)$ had more inhibitory effect. Inhibitory effects of EOs on xanthine oxidase have been reported from several plants for example Alpinia zerumbet [4], rice (Oryza sativa) leaf [30], and Foeniculum vulgare [31]. In line with our study, Tu and Tawata [4] reported the presence of monoterpenes and sesquiterpenes may be responsible to antyhiperuricemic property of EOs.

Allelopathic effects of water extract of $P$. nigrum leaves against several indicator plants such as Phaseolus radiatus, Raphanus sativus, Stylosanthes guianensis, and Amaranthus spinous have been reported. This water extract affected some antioxidant enzymes including superoxide dismutase (SOD), catalase (CAT) and peroxidase (POD) of Rhapanus sativus. It also stimulated malondiadehyde (MDA) accumulation of $R$. sativus seedling [32,33]. Furthermore, P. nigrum leaching has been noted to possess allelopathic effects on Vigna mungo [34]. However, both of P. cubeba and P. nigrum EOs have been not studied yet.

In the herbicidal assay, B. pilosa and E. crus-galli, two of the most problematic weeds, were employed as indicator plants. P. cubeba and P. nigrum EOs showed inhibitory effects on germination and growth of two indicator plants. Compared with P. nigrum EO, P. cubeba EO exhibited more inhibitory effects. In agreement with our results, several herbicidal activities of EOs have been attributed to the presence of flavonoids, saponins [1], sesquiterpenes [3], limonene, limonene-10-al [35], ocimenones, and spathulenol [36]. Some commercial oils such as limonene and caryophyllene oxide have reported to possess phytotoxic activity [37].

Allelochemicals from EOs generally affected chlorophyll synthesis. In our study, both of P. cubeba and P. nigrum EOs decreased chlorophyll a, b, total chlorophylls, and carotenoids contents of $B$. pilosa and E. crus-galli. P. cubeba EO reduced pigments contents by 41.76 to $49.43 \%$ stronger than $P$. nigrum at concentration $1.93 \mathrm{mg} / \mathrm{mL}$. These pigments reduction suggests that $P$. cubeba and $P$. nigrum EOs inhibited photosynthesis, due the loss of chlorophylls concentration in two of indicator plants. These results are similar with previous studies which reported that EOs reduced chlorophylls and carotenoid contents [1,38]. The reduction of chlorophylls and carotenoids contents may be because of the changes of either pigments biosynthesis or inhibition of enzyme protoporphyrinogen oxidase [39].

P. cubeba and P. nigrum EOs increased electrolyte leakage and MDA contents of B. pilosa and E. crus-galli at $1.93 \mathrm{mg} / \mathrm{mL}$ dose of treatments. This condition indicated that membranes of the two indicator plants were disrupted and loss of their integrity [40]. Our results agree with previous studies which reported that Artemesia scoparia and Tagetes erecta EOs induced electrolyte leakage and MDA accumulation [1,41]. Monoterpenes compounds have been reported to disrupt cell membrane permeability that stimulate MDA accumulation. Consequently, cellular potassium was leakage and inhibited glucose-dependent respiration [42].

Proline accumulations in B. pilosa and E. crus-galli increased when treated with P. cubeba and P. nigrum EOs $(1.93 \mathrm{mg} / \mathrm{mL})$ compared with control. Proline is a proteinogenic amino acid used in the biosynthesis of proteins. This amino acid accumulation is used for common physiological indicator in many plants in response to a wide range of biotic and abiotic stresses, for example, allelochemical stress. Increasing proline accumulation in B. pilosa and E. crus-galli may be a part of the stress signal influencing adaptive response due to allelochemicals from P. cubeba and P. nigrum EOs [40].

During stress, plants release secondary metabolites such as phenolics and flavonoids compounds. In our results, total phenolics and flavonoids contents were increased significantly in B. pilosa and 
E. crus-galli when treated by P. cubeba and P. nigrum EOs compared with control. Similar to our results, Ladhari et al. [43] reported that lettuce enhanced accumulation of total phenolic and flavonoid contents as an adaptive response to allelochemicals from Cleome arabica.

The GC-MS and LC-ESI-MS analyses revealed that monoterpenes and sesquiterpenes were the major components of P. cubeba and P. nigrum EOs. Bos et al. [17] reported the main components of $P$. cubeba EO extracted from its berries were $\beta$-elemene $(9.4 \%)$ and sabinene $(9.1 \%)$. In contrast, we detected terpinen-4-ol (42.41\%), $\alpha$-copaene $(20.04 \%)$, and $\gamma$-elemene (17.68) as the major components of $P$. cubeba EO. $\gamma$-Elemene is isomere of $\beta$-elemene, whereas sabinene was also detected in our study as trace element $(<0.02 \%)$ (data not shown). In case P. nigrum EO, $\beta$-caryophyllene $(51.12 \%)$ was the dominant compound detected. Similarly, Morshed et al. [22] and Bagheri et al. [27] reported $\beta$-caryophyllene was the main compound of P. nigrum EO. The changes of chemical components of EOs may have resulted from several factors such as environmental (climatic, geographic or seasonal) and genetic differences.

\section{Materials and Methods}

\subsection{Chemicals}

Potassium phosphate monobasic and dibasic, Folin-Ciocalteu's phenol, xanthine oxidase, xanthine, allopurinol, dimethyl sulfoxide (DMSO), hydrochloric acid, tricholoroacetic acid (TCA), Tween 20, thiobarbituric acid (TBA), proline, sulfosalicylic acid, glacial acetic acid, ninhydrin, and toluene were obtained from Sigma-Aldrich Japan K.K. (Tokyo, Japan). Sodium acetate, acetic acid, aluminium (III) chloride hexahydrate, 1,1-diphenyl-2-picrylhydrazyl (DPPH), dibutyl hydroxytoluene (BHT), and gallic acid were purchased from Kanto Chemical Co. Inc. (Tokyo, Japan). Acetone, potassium peroxodisulfate, 2,2'-azinobis (3-ethylbenzothiazoline-6-sulfonic acid) (ABTS) were obtained from Nacalai Tesque, Inc. (Kyoto, Japan). Methanol and ethanol at analytical grade were obtained from Junsei Chemical Co.; Ltd. (Tokyo, Japan).

\subsection{Plant Materials and Seeds}

Berries of Piper cubeba Bojer were purchased from a traditional market in Purworejo, Indonesia in 2016 and authenticated by Herbarium Bogoriense, Bogor, Indonesia. The samples were cleaned with tap water, sterilized and dried in an oven at $60{ }^{\circ} \mathrm{C}$ for three days before pulverized into a fine powder. The plant powder was then stored in sealed containers at $4{ }^{\circ} \mathrm{C}$ until used. Black pepper (Piper nigrum L.) powder was purchased commercially in Japan (Gaban, Co. Ltd.; Tokyo, Japan). The seeds of Bidens pilosa and Echinochloa crus-galli were collected in paddy fields on July 2017 in Higashi Hiroshima, Japan. The seeds germination was randomly tested and was $>80 \%$ germination.

\subsection{Essential Oils Extraction}

An amount of $300 \mathrm{~g}$ of dry powders of P. cubeba or P. nigrum was hydro-distilled with $2 \mathrm{~L}$ of water in a glass Clevenger-type apparatus for seven hours, as recommended by European Pharmacopoeia (ver. 8.2, Monograph 2.8.12). The essential oils collected were diluted with hexane to approximately $10 \mathrm{~mL}$, and vacuum evaporated at the ambient condition to obtain the neat oil. The EOs was then accurately weighed and stored at $4{ }^{\circ} \mathrm{C}$ for further analysis. Measurements were carried out in three replications. Essential oil yields (\%) were determined using the equation as follows [44]:

$$
\text { Essential oil }(\mathrm{EO})(\%)=\frac{\text { Mass of } \mathrm{EO}(\mathrm{g})}{\text { Dried materials }(\mathrm{g})} \times 100
$$




\subsection{Antioxidant Assays}

\subsubsection{DPPH Radical Scavenging Assay}

To evaluate the radical scavenging activity of $P$. cubeba and $P$. nigrum EOs, the 1,1-diphenyl-2-picryhydrazyl (DPPH) test was conducted following the method described previously [30]. Initially, samples or standard $(80 \mu \mathrm{L})$, DPPH solution $(40 \mu \mathrm{L}, 0.2 \mathrm{mM})$, and acetate buffer $(80 \mu \mathrm{L}, 0.1 \mathrm{M}, \mathrm{pH} 5.5)$ were mixed in a 96-wells microplate and kept at room temperature in the dark condition for $30 \mathrm{~min}$. The absorbance was recorded at $517 \mathrm{~nm}$ using a microplate reader (Multiskan ${ }^{\mathrm{TM}}$ Microplate Spectrophotometer, Thermo Fisher Scientific, Osaka, Japan) and butylated hydroxytoluene (BHT) $(10-100 \mu \mathrm{g} / \mathrm{mL})$ was used as a positive control. Percentage of inhibition was calculated as the following formula:

$$
\text { Radical scavenging }(\%)=\frac{\left(\mathrm{A}_{\text {control }}-\mathrm{A}_{\text {sample }}\right)}{\mathrm{A}_{\text {control }}} \times 100
$$

The term $\mathrm{A}_{\text {control }}$ is the absorbance of reaction without sample and $\mathrm{A}_{\text {sample }}$ is the absorbance of the reaction mixture with the sample. Antioxidant activity was expressed as $\mathrm{IC}_{50}$ values $(\mathrm{mg} / \mathrm{mL})$, the concentrations required to give $50 \% \mathrm{DPPH}$ radical scavenging activity.

\subsubsection{ABTS Radical Scavenging Assay}

A solution of 2,2'-azinobis (3-ethylbenzothiazoline-6-sulfonic acid) radical cation (ABTS) was employed to evaluate the radical scavenging activity of EOs according to a previously described method [45] with minor adjustments. The ABTS working solution was generated by a reaction of $7 \mathrm{mM}$ ABTS and $2.45 \mathrm{mM}$ potassium persulfate solution after incubation at room temperature in the dark for $16 \mathrm{~h}$. The mixture was then diluted with methanol until obtain an absorbance of $0.70 \pm 0.05$ at $734 \mathrm{~nm}$. Initially, the ABTS working solution $(120 \mu \mathrm{L})$ was added to samples $(24 \mu \mathrm{L})$ or standard containing different concentration. Finally, the mixture was incubated in the dark at ambient condition for $30 \mathrm{~min}$. The absorbance was recorded at $734 \mathrm{~nm}$ using microplate a reader (Multiskan ${ }^{\mathrm{TM}}$ Microplate Spectrophotometer, Thermo Fisher Scientific, Osaka, Japan). BHT standard $(5-125 \mu \mathrm{g} / \mathrm{mL})$ was used as a positive control. The calculation of ABTS radical scavenging activity was the same with DPPH method.

\subsection{Xanthine Oxidase Inhibitory Assay}

The xanthine oxidase $(\mathrm{XO})$ inhibitory activity was assayed spectrophotometrically in vitro under aerobic condition according to the method reported previously [46,47]. Briefly, a volume of $50 \mu \mathrm{L}$ sample or standard was mixed with $35 \mu \mathrm{L}$ of $70 \mathrm{mM}$ phosphate buffer $(\mathrm{pH}=7.5)$, and $30 \mu \mathrm{L}$ of fresh xanthine oxidase solution $(0.01$ units $/ \mathrm{mL}$ in $70 \mathrm{mM}$ phosphate buffer, $\mathrm{pH}=7.5)$ in a 96-well microplate. After pre-incubated at $25^{\circ} \mathrm{C}$ for $15 \mathrm{~min}$, the reaction was then initiated by adding $60 \mu \mathrm{L}$ of substrate solution ( $150 \mu \mathrm{M}$ xanthine in the same buffer) and incubated in the same temperature for $30 \mathrm{~min}$. To stop the reaction, a volume of $25 \mu \mathrm{L} \mathrm{HCl}(1 \mathrm{M})$ was added. The absorbance was recorded at $290 \mathrm{~nm}$ with a microplate reader. For the blank, the assay mixture was prepared in its present condition, but the enzyme solution was pipetted after adding $\mathrm{HCl}$. One unit of $\mathrm{XO}$ was defined as the amount of enzyme required to produce one $\mu \mathrm{mol}$ of uric acid/min at $25^{\circ} \mathrm{C}$. The $\mathrm{XO}$ inhibitory activity was calculated as follows:

$$
\text { Inhibition }(\%)=\left\{\frac{\{A-B\}-\{C-D\}}{A-B}\right\} \times 100
$$

where $\mathrm{A}$ is the absorbance of the mixture assay without test sample, $\mathrm{B}$ is the control of $\mathrm{A}$ without test sample and enzyme, $\mathrm{C}$ and $\mathrm{D}$ are the absorbances of test sample with and without $\mathrm{XO}$, respectively. Allopurinol $(10-100 \mu \mathrm{g} / \mathrm{mL})$ was used as a positive control. The $\mathrm{IC}_{50}$ values were calculated from the mean values of percentage inhibition data. 


\subsection{Herbicidal Assays}

The herbicidal assays were conducted according to the method reported previously [39]. P. cubeba and P. nigrum EOs were dispersed in Tween 20 and subsequently diluted with distilled water to obtain several concentrations of samples (final concentration of Tween $20<0.02 \%$ ). A volume of $300 \mu \mathrm{L}$ of sample was pipetted in a 12-well plate $(22.1 \mathrm{~mm}$ diameter $\times 35 \mathrm{~mm})$ lined with filter paper. The seeds of B. pilosa and E. crus-galli were sterilized with sodium hypochlorite ( $5 \%$ ) for $5 \mathrm{~min}$, rinsed by distilled water, and placed in the well plate. The well plates were then kept in a growth chamber (Biotron NC system, Nippon Medical \& Chemical Instrument, Co. Ltd.; Osaka, Japan) and additional volume of $50 \mu \mathrm{L}$ distilled water was added subsequently at 2 to 5 days. Photoperiod was set up $12 / 12 \mathrm{~h}$ day/night with temperature $28 / 25^{\circ} \mathrm{C}$. After five days, germination percentages, and root and shoot lengths over the controls were recorded and expressed as the percentage of inhibition. The $\mathrm{IC}_{50}$ value presented the concentration required to inhibit $50 \%$ of germination, shoot height, and root length was also calculated.

\subsection{Physiological and Biochemical Responses}

\subsubsection{Chlorophyll and Carotenoid Contents}

The chlorophylls ( $a, b$, and total chlorophylls) and carotenoids were determined following the method reported previously [48]. An amount of $100 \mathrm{mg}$ fresh weight leaves of 5-days old B. pilosa or E. crus-galli seedlings was placed in a microtube, ground, and added $1.5 \mathrm{~mL}$ of $80 \%$ acetone. After centrifugation at 15,000 rpm, the supernatant of the mixture was recorded at $663,645 \mathrm{~nm}$ and $440 \mathrm{~nm}$ using a microplate reader (Multiskan ${ }^{\mathrm{TM}}$ Microplate Spectrophotometer). The pigment contents were expressed as $\mu \mathrm{g} / \mathrm{mg}$ fresh weight and calculated following the equations:

$$
\begin{gathered}
\text { Total chlorophyll }(\mathrm{mg} / \mathrm{g})=20.2 \text { A645 + 8.02 A663 } \\
\text { Chlorophyll a }(\mathrm{mg} / \mathrm{g})=12.7 \text { A663 }-2.69 \text { A645 } \\
\text { Chlorophyll b }(\mathrm{mg} / \mathrm{g})=22.9 \text { A645 - 4.68 A663 } \\
\text { Carotenoids }(\mathrm{mg} / \mathrm{g})=(4.7 \text { A440 }-(1.38 \text { A663 + 5.48 A645) })
\end{gathered}
$$

\subsubsection{Electrolyte Leakage}

The electrolyte leakage (EL) was determined by the method described previously [49]. The amount of $100 \mathrm{mg}$ freshly leaves or aerial parts of B. pilosa and E. crus-galli seedlings (control or treatment) were cut and floated in a tube containing $15 \mathrm{~mL}$ of distilled water. The tubes were kept at ambient condition for 24 and $48 \mathrm{~h}$ and the initial electrical conductivity of the medium $\left(\mathrm{EC}_{1}\right)$ was measured with a digital conductivity meter (EC Meter CM-14P, TOA Electronics Co.; Ltd.; Nagoya, Japan). After that, the samples were autoclaved at $121{ }^{\circ} \mathrm{C}$ for $20 \mathrm{~min}$ to release all electrolytes, cooled down to $25^{\circ} \mathrm{C}$, and the final electrical conductivity $\left(\mathrm{EC}_{2}\right)$ were measured. The electrolyte leakage (EL) was calculated according to the following formula [50]:

$$
\text { Electrolyte Leakage }(\%)=\left(\frac{E C_{1}}{\mathrm{EC}_{2}}\right) \times 100
$$

\subsubsection{Lipid Peroxidation}

The lipid peroxidation was estimated by measuring the amount of malondialdehyde (MDA) accumulation according to the method described previously [51]. Fresh samples of roots and aerial parts of B. pilosa or E. crus-galli $(100 \mathrm{mg})$ were ground and homogenized in $1.5 \mathrm{~mL}$ of $0.1 \%$ trichloroacetic acid (TCA). Afterward, the homogenate was centrifuged at $15,000 \mathrm{rpm}$ and $4{ }^{\circ} \mathrm{C}$ for $20 \mathrm{~min}$. The supernatant $(250 \mu \mathrm{L})$ was transferred to a microtube and added $750 \mu \mathrm{L} 0.5 \%$ thiobarbituric acid (TBA) in $20 \%$ TCA. The mixture was then incubated at $90{ }^{\circ} \mathrm{C}$ for $10 \mathrm{~min}$ in a dry bath incubator (MS-100 Thermo 
Shaker Incubator, On Wing Tat Co. Ltd.; Kowloon, Hong Kong) and cooled in an ice bath for five min. After centrifugation at $10,000 \mathrm{rpm}$ and $4{ }^{\circ} \mathrm{C}$ for $5 \mathrm{~min}$, the absorbance of supernatant was recorded at 532 and $600 \mathrm{~nm}$ by using a microplate reader (Multiskan ${ }^{\mathrm{TM}}$ Microplate Spectrophotometer). The MDA accumulation was calculated using the $\Delta$ (A532 - A600) equation and an extinction coefficient $(\varepsilon=155 \mathrm{~m} / \mathrm{M} / \mathrm{cm})$. The results were expressed as $\mathrm{nmol} \mathrm{MDA} / \mathrm{g}$ fresh weight by following the equation:

$$
\operatorname{MDA}(\mathrm{mM} / \mathrm{L})=\left(\mathrm{A}_{532}-\mathrm{A}_{600}\right) / \varepsilon
$$

\subsubsection{Proline Contents}

The proline accumulations of B. pilosa and E. crus-galli were measured according to the method reported previously [52]. Initially, $10 \mathrm{mg}$ of powder of dry roots and aerial parts from the two indicator plants were homogenized with $1.5 \mathrm{~mL}$ of $3 \%$ sulfosalicylic acid. The homogenate solution was centrifuged at $14,000 \mathrm{rpm}$ for $10 \mathrm{~min}$. The supernatant $(250 \mu \mathrm{L})$ from each homogenate was mixed with $250 \mu \mathrm{L}$ glacial acetic acid and $250 \mu \mathrm{L}$ ninhydrin reagent $(1.25 \mathrm{~g}$ ninhydrin in $30 \mathrm{~mL}$ glacial acetic and $20 \mathrm{~mL} 6 \mathrm{M} \mathrm{H}_{3} \mathrm{PO}_{4}$ ) in a fresh tube. After, the tubes were incubated at $100{ }^{\circ} \mathrm{C}$ for $1 \mathrm{~h}$ in a water bath and they rapidly cooled in an ice bath to stop the reaction. Finally, $500 \mu \mathrm{L} \mathrm{mL}$ of toluene was added to each tube. The absorbance of the pink-red upper phase was recorded at $520 \mathrm{~nm}$ against toluene blank. L-Proline $(2.5$ to $50 \mu \mathrm{g} / \mathrm{mL})$ was used as a standard.

\subsubsection{Total Phenolic Contents}

The Folin Ciocalteu (FC) reagent was used to measure total phenolic accumulations of B. pilosa and E. crus-galli following the method reported previously [53] with minor modifications. A volume of $20 \mu \mathrm{L}$ of either sample solution $(1.0 \mathrm{mg} / \mathrm{mL})$, or gallic acid standard solution $(5-25 \mu \mathrm{g} / \mathrm{mL})$ was pipetted into separate wells of a 96-well microplate. A volume of $100 \mu \mathrm{L}$ of the FC reagent $(10 \% v / v$ in water) was added to each well, thoroughly mixed, and an aliquot of $80 \mu \mathrm{L}$ sodium carbonate $(5 \% w / v$ in water) was then added. The reaction mixture was then incubated at ambient condition for $30 \mathrm{~min}$ and the absorbance was read at $765 \mathrm{~nm}$ by using a microplate reader. The total phenolic contents were expressed as mg gallic acid equivalent (GAE) per gram of fresh weight $\left(\mathrm{r}^{2}=0.996\right)$.

\subsubsection{Total Flavonoid Contents}

The total flavonoid contents of B. pilosa and E. crus-galli were assessed by a colorimetric assay as described previously [53]. Briefly, a volume of either $100 \mu \mathrm{L}$ sample $(1 \mathrm{mg} / \mathrm{mL})$ or standard $(5-25 \mu \mathrm{g} / \mathrm{mL})$ was mixed with $100 \mu \mathrm{L}$ aluminum (III) chloride hexahydrate ( $2 \% w / v$ in water) in a 96-wells-microplate. After a 15-min incubation at room temperature, the absorbance of the reaction mixture was measured at $430 \mathrm{~nm}$ using a microplate reader. The total flavonoid contents were expressed as mg quercetin equivalent $(\mathrm{QE})$ per gram of fresh weight $\left(\mathrm{r}^{2}=0.999\right)$.

\subsubsection{Identification of Chemical Constituents by Gas Chromatography-Mass Spectrometry (GC-MS)}

A volume of $1 \mu \mathrm{L}$ of each sample was injected into a GC-MS system (JMS-T100 GCV, JEOL Ltd.; Tokyo, Japan). The column was DB-5MS with $30 \mathrm{~m}$ in length, $0.25 \mathrm{~mm}$ internal diameter, and $0.25 \mu \mathrm{m}$ in thickness (Agilent Technologies, J \& W Scientific Products, Folsom, CA, USA). Helium was chosen as a carrier gas, and the split ratio was 5.0/1.0. The operating condition of GC oven temperature was maintained as follows: the initial temperature was set up at $50{ }^{\circ} \mathrm{C}$ without hold time, the temperature was increased at a rate of $10^{\circ} \mathrm{C} / \mathrm{min}$ up to a final temperature of $300^{\circ} \mathrm{C}$ (hold for $20 \mathrm{~min}$ ). The injector and detector temperatures were set at $300^{\circ} \mathrm{C}$ and $320^{\circ} \mathrm{C}$, respectively. The mass range scanned from 29-800 amu. The obtained peak was analyzed using JEOL's GC-MS Mass Center System version 2.65a.

\subsubsection{Liquid Chromatography-Electrospray Ionization-Mass Spectrometry (LC-ESI-MS) Analysis}

Chemical composition of P. cubeba and P. nigrum EOs detected in GC-MS system both for volatile and non-volatile components were confirmed by LC-ESI-MS system (Thermo Fisher Scientific ${ }^{\mathrm{TM}}$, 
LTQ XLTM, Ion Trap Mass Spectrometer, Tokyo, Japan) [47]. The column used for the LC system was a JASCO J-Pak Symphonia C18 $(250 \mathrm{~mm} \times 4.6 \mathrm{~mm} \times 5 \mu \mathrm{m})$. Two solvents for the mobile phase were $0.1 \%$ formic acid in water (solvent $\mathrm{A}$ ) and $0.1 \%$ formic acid in acetonitrile (solvent $\mathrm{B}$ ). The proportion of these solvents was 30:70 (A:B), flowrate was $0.4 \mathrm{~mL} / \mathrm{min}$, volume of sample injection was $5 \mu \mathrm{L}$, and operation time was $30 \mathrm{~min}$. For ESI-MS, the flow rate of sheath gas was 60 , while auxiliary gas was 20 arbitrary units of sheath gas. The spray voltage was $4.5 \mathrm{kV}$. The measurements were performed in the positive mode. For positive polarity, Fourier transform mass spectrometry (FTMS)/orbitrap with 60,000 resolutions, and scan ranged from $100-1000 \mathrm{~m} / \mathrm{z}$ was applied for mass analysis. For negative polarity, ion trap mass spectrometer (ITMS)/linear ion trap with scan range 115-1000 m/z was employed [54]. Peak processing was conducted using Thermo Xcalibur Qual Browser software (ThermoScientific ${ }^{\mathrm{TM}}$ ) equipped with NIST MS Library.

\subsubsection{Statistical Analysis}

The statistical analysis was conducted in one-way ANOVA using Minitab ${ }^{\circledR}$ 16.2.3 $\left({ }^{(}\right) 2012$ Minitab Inc.; Philadelphia, PA, USA). The results were expressed as means \pm standard deviation (SD) values. The significant difference among treatments, controls, and standards were determined by using Fisher's test with the confidence level of $95 \%(p<0.05)$.

\section{Conclusions}

P. cubeba and P. nigrum EOs are the volatile oils contented rich bioactive sources and healthy values. In this study, we found that these EOs possessed antioxidant, antihyperuricemic, and herbicidal activities. Compared with P. nigrum EO, P. cubeba EO indicated stronger of antioxidant, antihyperuricemic, and herbicidal activities. In the herbicidal assay, P. cubeba decreased chlorophyll a, b, total chlorophylls, and carotenoids contents of B. pilosa and E. crus-galli, but induced electrolyte leakage, lipid peroxidation, total phenolic, total flavonoid, and proline contents. GC-MS and LC-ESI-MS analyses revealed that P. cubeba and P. nigrum EOs had complex mixture of compounds that consisted of monoterpenes and sesquiterpenes. Terpinen-4-ol (42.41\%), followed by $\alpha$-copaene $(20.04 \%)$ and $\gamma$-elemene $(17.68 \%)$ were accounted as the major components of $P$. cubeba EO. Whereas, $\beta$-caryophyllene $(51.12 \%)$ and $\beta$-thujene $(20.58 \%)$ were the dominant components of $P$. nigrum EO. Findings of this study suggested that $P$. cubeba and $P$. nigrum EOs are promising source to treat oxidative stress and antihyperuricemia diseases as well as natural herbicide against B. pilosa and E. crus-galli.

Supplementary Materials: Figures S1-S24 and Tables S1-S22 are provided. Figures S1 and S13 are GC-MS chromatogram of P. cubeba and P. nigrum EOs. Tables S1-S12 are GC-MS fragmentation pattern, Figures S2a-S13a are GC-MS mass spectra, and Figures S2b-S13b are LC-ESI-MS spectra by H+ ion adduction for terpinen-4-ol, trans-chrysanthenyl acetate, $\delta$-elemene, $\alpha$-cubebene, $\alpha$-copaene, d-germacrene, $\gamma$-elemene, $\delta$-cadinene, $\alpha$-elemol, spathulenol, cubenol, and $\beta$-eudesmol detected in P. cubeba EO, respectively. Tables S13-S22 are GC-MS fragmentation pattern, Figures S14a-S24a are GC-MS mass spectra, and Figures S14b-S24b are LC-ESI-MS spectra by $\mathrm{H}+$ ion adduction for $\beta$-thujene, terpinen-4-ol, $\delta$-elemene, $\alpha$-copaene, $\beta$-caryophyllene, humulene, $\beta$-selinene, $\delta$-cadinene, caryophyllene oxide, and cubenol detected in P. nigrum EO.

Author Contributions: Y.A. and T.N.Q. conceptualized and implemented the experiments. Y.A.; T.N.Q. analyzed data and wrote the manuscript. T.D.X. supervised this research. Q.-T.L. and H.-D.T. and T.D.X. revised the manuscript. All authors agreed with the final version of the manuscript.

Funding: This research received no external funding.

Acknowledgments: The authors are grateful to The Ministry of Education, Culture, Sports, Science, and Technology (MEXT), Japan for financial support to Yusuf Andriana under Super Global University scholarship. The authors are also thankful to all of lab members for their support to this research. Thanks are also due to Nguyen Tat Thanh University, and 7A Military Hospital, Vietnam and Kume Sangyo, Japan for their partial support to this research.

Conflicts of Interest: The authors declare no conflict of interest. 


\section{References}

1. Laosinwattana, C.; Wichittrakarn, P.; Teerarak, M. Chemical composition and herbicidal action of essential oil from Tagetes erecta L. leaves. Ind. Crop. Prod. 2018, 126, 129-134. [CrossRef]

2. Prakash, B.; Mishra, P.K.; Kedia, A.; Dubey, N.K. Antifungal, antiaflatoxin and antioxidant potential of chemically characterized Boswellia carterii Birdw essential oil and its in vivo practical applicability in preservation of Piper nigrum L. fruits. LWT Food Sci. Technol. 2014, 56, 240-247. [CrossRef]

3. Abd El-Gawad, A.M. Chemical constituents, antioxidant and potential allelopathic effect of the essential oil from the aerial parts of Cullen plicata. Ind. Crops Prod. 2016, 80, 36-41. [CrossRef]

4. Tu, P.T.B.; Tawata, S. Anti-oxidant, anti-aging, and anti-melanogenic properties of the essential oils from two varieties of Alpinia zerumbet. Molecules 2015, 20, 16723-16740. [CrossRef]

5. Hazrati, H.; Saharkhiz, M.J.; Niakousari, M.; Moein, M. Natural herbicide activity of Satureja hortensis L. essential oil nanoemulsion on the seed germination and morphophysiological features of two important weed species. Ecotoxicol. Environ. Saf. 2017, 142, 423-430. [CrossRef] [PubMed]

6. Fagodia, S.K.; Singh, H.P.; Batish, D.R.; Kohli, R.K. Phytotoxicity and cytotoxicity of Citrus aurantiifolia essential oil and its major constituents: Limonene and citral. Ind. Crops Prod. 2017, 108, 708-715. [CrossRef]

7. Ben Ghnaya, A.; Amri, I.; Hanana, M.; Gargouri, S.; Jamoussi, B.; Romane, A.; Hamrouni, L. Tetraclinis articulata (Vahl.) Masters essential oil from Tunisia: Chemical characterization and herbicidal and antifungal activities assessment. Ind. Crops Prod. 2016, 83, 113-117. [CrossRef]

8. Mesquita, J.M.O.; Oliveira, A.B.; Braga, F.C.; Lombardi, J.A.; da Cunha, A.P.; Salgueiro, L.; Cavaleiro, C. Essential oil constituents of Piper vicosanum Yunker from the Brazilia Atlantic Forest. J. Essent. Oil Res. 2006, 18, 392-395. [CrossRef]

9. Hoff Brait, D.R.; Mattos Vaz, M.S.; da Silva Arrigo, J.; Borges de Carvalho, L.N.; Souza de Araújo, F.H.; Vani, J.M.; da Silva Mota, J.; Cardoso, C.A.L.; Oliveira, R.J.; Negrão, F.J.; et al. Toxicological analysis and anti-inflammatory effects of essential oil from Piper vicosanum leaves. Regul. Toxicol. Pharmacol. 2015, 73, 699-705. [CrossRef]

10. De Morais, S.M.; Facundo, V.A.; Bertini, L.M.; Cavalcanti, E.S.B.; dos Anjos, J.F., Jr.; Ferreira, S.A.; de Brito, E.S.; de Souza Neto, M.A. Chemical composition and larvicidal activity of essential oils from Piper species. Biochem. Syst. Ecol. 2007, 35, 670-675. [CrossRef]

11. Bosquiroli, L.S.S.; Demarque, D.P.; Rizk, Y.S.; Cunha, M.C.; Marques, M.C.S.; De Matos, M.F.C.; Kadri, M.C.T.; Carollo, C.A.; Arruda, C.C.P. In vitro anti-leishmania infantum activity of essential oil from Piper angustifolium. Braz. J. Pharmacogn. 2015, 25, 124-128. [CrossRef]

12. Nahak, G.; Sahu, R.K. Phytochemical evaluation and antioxidant activity of Piper cubeba and Piper nigrum. J. Appl. Pharm. Sci. 2011, 01, 153-157.

13. Elfahmi, K.R.; Batterman, S.; Bos, R.; Kayser, O.; Woerdenbag, H.J.; Quax, W.J. Lignan profile of Piper cubeba, an Indonesian medicinal plant. Biochem. Syst. Ecol. 2007, 35, 397-402. [CrossRef]

14. Magalhães, L.G.; de Souza, J.M.; Wakabayashi, K.A.L. In vitro efficacy of the essential oil of Piper cubeba L. (Piperaceae) against Schistosoma mansoni. Parasitol. Res. 2012, 110, 1747-1754. [CrossRef]

15. Mothana, R.; Alsaid, M.; Khaled, J.M.; Alharbi, N.S.; Alatar, A.; Raish, M.; Al-Yahya, M.; Rafatullah, S.; Parvez, M.K.; Ahamad, S.R. Assessment of antinociceptive, antipyretic and antimicrobial activity of Piper cubeba L. essential oil in animal models. Pak. J. Pharm. Sci. 2016, 29, 671-677. [PubMed]

16. Chaubey, M.K. Insecticidal properties of Zingiber officinale and Piper cubeba essential oils against Tribolium castaneum Herbst (Coleoptera: Tenebrionidae). J. Biol. Act. Prod. Nat. 2011, 1, 306-313.

17. Bos, R.; Woerdenbag, H.J.; Kayser, O.; Quax, W.J.; Ruslan, K.; Elfami. Essential oil constituents of Piper cubeba L. fils. from Indonesia. J. Essent. Oil Res. 2007, 19, 14-17. [CrossRef]

18. Vinturelle, R.; Mattos, C.; Meloni, J.; Nogueira, J.; Nunes, M.J.; Jr, I.S.V.; Rocha, L.; Lione, V.; Castro, H.C.; das Chagas, E.F. In vitro evaluation of essential oils derived from Piper nigrum (Piperaceae) and Citrus limonum (Rutaceae) against the tick Rhipicephalus (Boophilus) microplus (Acari: Ixodidae). Biochem. Res. Int. 2017, 1-9. [CrossRef]

19. Upadhyay, R.K.; Jaiswal, G. Evaluation of biological activities of Piper nigrum oil against Tribolium castaneum. Bull. Insectol. 2007, 60, 57-61.

20. Amer, A.; Mehlhorn, H. Larvicidal effects of various essential oils against Aedes, Anopheles, and Culex larvae (Diptera, Culicidae). Parasitol. Res. 2006, 99, 466-472. [CrossRef] 
21. Morsy, N.F.S.; Abd El-Salam, E.A. Antimicrobial and antiproliferative activities of black pepper (Piper nigrum L.) essential oil and oleoresin. J. Essent. Oil Bear. Plants 2017, 20, 779-790. [CrossRef]

22. Morshed, S.; Hossain, M.D.; Ahmad, M.; Junayed, M. Physicochemical characteristics of essential oil of black pepper (Piper nigrum) cultivated in Chittagong, Bangladesh. J. Food Qual. Hazards Control 2017, 4, 66-69.

23. Hari, R.; Vasuki, R.; Prasoon, G.P.; Singh, H.P.; Mishra, N. Evaluation of in-vitro antioxidant and xanthine oxidase inhibitory activity of selected Indian plants. Int. J. Biotech. Trend Tech. 2012, 2, 1-9.

24. Gawlik-Dziki, U. Dietary spices as a natural effectors of lipoxygenase, xanthine oxidase, peroxidase and antioxidant agents. LWT Food Sci. Technol. 2012, 47, 138-146. [CrossRef]

25. Sabina, E.P.; Nagar, S.; Rasool, M. A role of piperine on monosodium urate crystal-induced inflammation-an experimental model of gouty arthritis. Inflammation 2011, 34, 184-192. [CrossRef] [PubMed]

26. William, E.A., Jr.; James, S.C. Phase transition enthalpy measurements of organic and organometallic compounds. In NIST Chemistry WebBook, NIST Standard Reference Database Number 69; Linstrom, P.J., Mallard, W.G., Eds.; National Institute of Standards and Technology: Gaithersburg, MD, USA, 2018.

27. Bagheri, H.; Abdul Manap, M.Y.; Abdul Manap, M.Y.B.A.; Solati, Z. Antioxidant activity of Piper nigrum L. essential oil extracted by supercritical CO2 extraction and hydro-distillation. Talanta 2014, 121, 220-228.

28. Zaka, M.S.; Iqbal, N.; Saeed, Q.; Akrem, A.; Batool, M.; Khan, A.A.; Anwar, A.; Bibi, M.; Azeem, S.; Rizvi, D.; et al. Toxic effects of some insecticides, herbicides, and plant essential oils against Tribolium confusum Jacquelin du val (Insecta: Coleoptera: Tenebrionidae). Saudi J. Biol. Sci 2018, in press. [CrossRef]

29. Elzaawely, A.A.; Xuan, T.D.; Koyama, H.; Tawata, S. Antioxidant activity and contents of essential oil and phenolic compounds in flowers and seeds of Alpinia zerumbet (Pers.) B.L. Burtt. \& R.M. Sm. Food Chem. 2007, 104, 1648-1653.

30. Minh, T.N.; Xuan, T.D.; Van, T.M.; Andriana, Y.; Viet, T.D.; Khanh, T.D.; Tran, H.-D. Phytochemical analysis and potential biological activities of essential oil from rice leaf. Molecules 2019, 24, 889. [CrossRef] [PubMed]

31. García, P.; Ramallo, I.A.; Salazar, M.O.; Furlan, R.L.E. Chemical diversification of essential oils, evaluation of complex mixtures and identification of a xanthine oxidase inhibitor. RSC Adv. 2016, 6, 57245-57252. [CrossRef]

32. Yan, G.; Zhu, C.; Luo, Y.; Yang, Y.; Wei, J. Potential allelopathic effects of Piper nigrum, Mangifera indica and Clausena lansium. J. App. Ecol. 2006, 17, 1633-1636. (in Chinese).

33. Sheng-li, Z.H.A.N. Preliminary study on the allelopathy of Piper nigrum L. Available online: http://en.cnki. com.cn/Article_en/CJFDTotal-AHNY200903016.htm (accessed on 12 May 2019).

34. Siddiqui, Z.S. Allelopathic effects of black pepper leachings on Vigna mungo (L.) Hepper. Acta Physiol. Plant. 2007, 29, 303-308. [CrossRef]

35. Jalaei, Z.; Fattahi, M.; Aramideh, S. Allelopathic and insecticidal activities of essential oil of Dracocephalum kotschyi Boiss. from Iran: A new chemotype with highest limonene-10-al and limonene. Ind. Crops Prod. 2015, 73, 109-117. [CrossRef]

36. López, M.L.; Bonzani, N.E.; Zygadlo, J.A. Allelopathic potential of Tagetes minuta terpenes by a chemical, anatomical and phytotoxic approach. Biochem. Syst. Ecol. 2008, 36, 882-890. [CrossRef]

37. Dias, J.F.G.; Miguel, O.G.; Miguel, M.D. Composition of essential oil and allelopathic activity of aromatic water of Aster lanceolatus Willd: (Asteraceae). Braz. J. Pharm. Sci. 2009, 45, 469-474. [CrossRef]

38. Almarie, A.A.; Mamat, A.S.; Wahab, Z.; Rukunudin, I.H. Chemical composition and phytotoxicity of essential oils isolated from Malaysian plants. Allelopath. J. 2016, 37, 55-70.

39. Andriana, Y.; Xuan, T.D.; Quan, N.V.; Quy, T.N. Allelopathic potential of Tridax procumbens L. on radish and identification of allelochemicals. Allelopath. J. 2018, 43, 223-238. [CrossRef]

40. Jaballah, S.B.; Zribi, I.; Haouala, R. Physiological and biochemical responses of two lentil varieties to chickpea (Cicer arietinum L.) aqueous extracts. Sci. Hortic. 2017, 225, 74-80. [CrossRef]

41. Kaur, S.; Singh, H.P.; Mittal, S.; Batish, D.R.; Kohli, R.K. Phytotoxic effects of volatile oil from Artemisia scoparia against weeds and its possible use as a bioherbicide. Ind. Crops Prod. 2010, 32, 54-61. [CrossRef]

42. Mutlu, S.; Atici, Ö.; Esim, N.; Mete, E. Essential oils of catmint (Nepeta meyeri Benth.) induce oxidative stress in early seedlings of various weed species. Acta Physiol. Plant. 2011, 33, 943-951. [CrossRef]

43. Ladhari, A.; Omezzine, F.; Haouala, R. The impact of Tunisian Capparidaceae species on cytological, physiological and biochemical mechanisms in lettuce. South Afr. J. Bot. 2014, 93, 222-230. [CrossRef]

44. Zhang, D.-Y.; Yao, X.-H.; Duan, M.-H.; Wei, F.-Y.; Wu, G.-H.; Li, L. Variation of essential oil content and antioxidant activity of Lonicera species in different sites of China. Ind. Crops Prod. 2015, 77, 772-779. [CrossRef] 
45. Quan, N.V.; Dang, X.T.; Tran, H.-D.; Thuy, N.T.D.; Trang, L.T.; Huong, C.T.; Andriana, Y.; Tuyen, P.T. Antioxidant, $\alpha$-amylase and $\alpha$-glucosidase inhibitory activities and potential constituents of Canarium tramdenum Bark. Molecules 2019, 24, 482. [CrossRef] [PubMed]

46. Nguyen, M.T.T.; Awale, S.; Tezuka, Y.; Le Tran, Q.; Watanabe, H.; Kadota, S. Xanthine oxidase inhibitory activity of Vietnamese medicinal plants. Biol. Pharm. Bull. 2004, 27, 1414-1421. [CrossRef] [PubMed]

47. Andriana, Y.; Xuan, T.D.; Quy, T.N.; Ngoc, M.T.; Van, T.M.; Viet, T.D. Antihyperuricemia, antioxidant, and antibacterial activities of Tridax procumbens L. Foods 2019, 8, 21. [CrossRef] [PubMed]

48. Lichtenthaler, H.; Wellburn, A. Determinations of total carotenoids and chlorophylls b of leaf extracts in different solvents. Biochem. Soc. Trans. 1983, 11, 591-592. [CrossRef]

49. Physiological and biochemical mechanisms of allelochemicals in aqueous extracts of diploid and mixoploid Trigonella foenum-graecum L. South African J. Bot. 2014, 93, 167-178. [CrossRef]

50. Lutts, S.; Kinet, J.M.; Bouharmont, J. NaCl-induced senescence in leaves of rice (Oryza sativa L.) cultivars differing in salinity resistance. Ann. Bot. 1996, 78, 389-398. [CrossRef]

51. Jaleel, C.A.; Gopi, R.; Sankar, B.; Manivannan, P.; Kishorekumar, A.; Sridharan, R.; Panneerselvam, R. Studies on germination, seedling vigour, lipid peroxidation and proline metabolism in Catharanthus roseus seedlings under salt stress. South Afr. J. Bot. 2007, 73, 190-195. [CrossRef]

52. Bates, L.S.; Waldren, R.P.; Teare, I.D. Rapid determination of free proline for water-stress studies. Plant Soil 1973, 39, 205-207. [CrossRef]

53. Elzaawely, A.A.; Tawata, S. Antioxidant capacity and phenolic content of Rumex dentatus L. grown in Egypt. J. Crop Sci. Biotechnol. 2012, 15, 59-64. [CrossRef]

54. Banerjee, S.; Mazumdar, S. Electrospray ionization mass spectrometry: A technique to access the information beyond the molecular weight of the analyte. Int. J. Anal. Chem. 2012, 2012, 1-40. [CrossRef] [PubMed]

Sample Availability: Samples of P. cubeba and P. nigrum EOs are available from the authors.

(C) 2019 by the authors. Licensee MDPI, Basel, Switzerland. This article is an open access article distributed under the terms and conditions of the Creative Commons Attribution (CC BY) license (http://creativecommons.org/licenses/by/4.0/). 